\title{
THE EFFECT OF PLASMA NITRIDING ON CAVITATION EROSION RESISTANCE OF GRAY CAST IRON WITH LAMELLAR GRAPHITE, EN-GJL-200
}

\author{
${ }^{1}$ Eduard RIEMSCHNEIDER, ${ }^{1}$ Ilare BORDEAȘU, ${ }^{1}$ Ion MITELEA, ${ }^{1}$ Ion-Dragoș UȚU, \\ ${ }^{1}$ Cornelius Marius CRĂCIUNESCU \\ ${ }^{1}$ Polytehnica University of Timisoara, Faculty of Mechanics, Timisoara, Timis, Romania, EU, \\ eduard.riemschneider@student.upt.ro, ilare.bordeasu@upt.ro, ion.mitelea@upt.ro,dragos.utu@upt.ro, \\ corneliu.craciunescu@upt.ro
}

https://doi.org/10.37904/metal.2021.4137

\begin{abstract}
Numerous engineering components which are in contact with liquid environments that are working under pressure can be degraded by cavitation erosion.

The present paper study the improvement of cavitation erosion resistance of gray cast iron with lamellar graphite and pearlite microstructure by applying the nitriding thermochemical treatment.

The cavitation tests were carried out on a vibratory device with piezoceramic crystals in accordance with ASTM G32 - 2016 standard.

The material degradation is demonstrated by mass loss and erosion rate variation depending on the cavitation attack period. As reference material it was considered the same type of gray cast iron, subjected to softening annealing treatment. The eroded surface was examined by optical and scanning electronic microscopy.
\end{abstract}

Keywords: Grey cast iron, cavitation erosion, plasma nitriding

\section{INTRODUCTION}

Plasma nitriding is a modern method of surface hardening where the heating of the parts is obtained as an effect of hitting the cathode (sample) by the ionized molecules of the used gas [1]. Compared to the classic ammonia method, it has the advantage of high nitriding rates, so that the total duration of this process can be reduced 2-3 times [1]. Since both the chemical parameters (chemical composition, pressure, flow) of the gas can be adjusted, as well as the electrical parameters (voltage, intensity of the luminescent discharge current), a nitride layer can be obtained with superior characteristics to the one obtained by the classical method.

Based on these remarks, the research carried out in this paper aims at the possibility of expanding the application of this technology to surfaces found in cavitational flows, where hardness plays an essential role in increasing the operating time.

\section{THE RESEARCHED MATERIAL. EQUIPMENT AND USED METHOD}

The experiments were conducted on cavitation samples [5-7] made of gray cast iron EN-GJL-200 with a microstructure composed of a pearlite metallic matrix with lamellar type A graphite separations (according to ASTM-67) and small amounts of phosphorous eutectic [6]. The samples were subjected to stress relieving annealing treatment at $525{ }^{\circ} \mathrm{C} / 4 \mathrm{~h} /$ oven, after that some samples were subjected to plasma nitriding thermochemical treatment at temperature of $530^{\circ} \mathrm{C}$, with a holding time of $840 \mathrm{~min}$, then cooled in the oven to $150^{\circ} \mathrm{C}$, and further air cooled at which point they were exposed into the air (Figure 1). Following this thermochemical treatment, the surface hardness reached to values of $368 \mathrm{HV} 5$. 


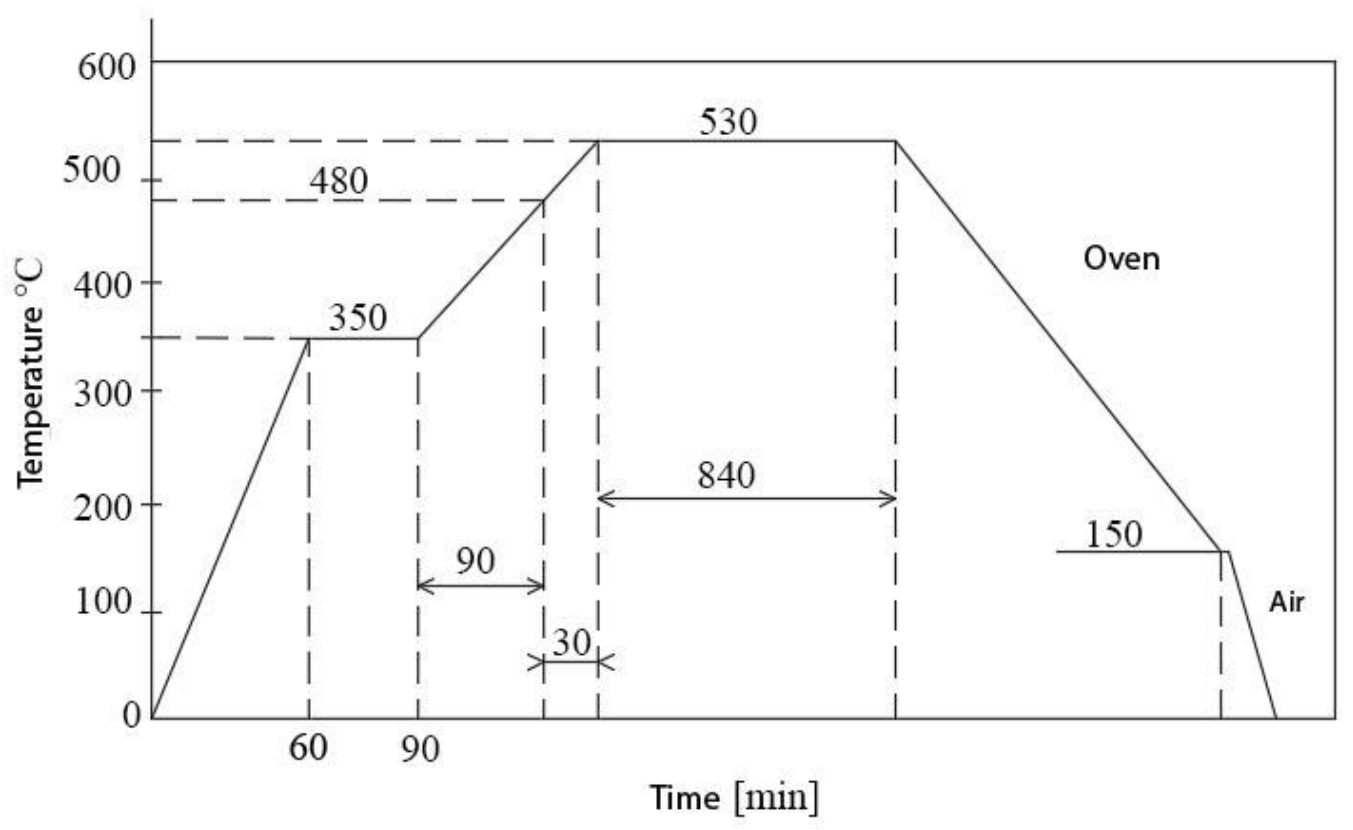

Figure 1 Cyclogram of thermochemical nitriding treatment

The analysis of the surface resistance of stress relieving annealing and plasma nitriding at cavitation erosion, was performed on sets of three samples, using the standard vibrating device with piezoceramic crystals (Figure 2), found in the Cavitation Laboratory of the Politehnica University of Timisoara. Before exposure to cavitation attack, the surfaces were polished to a roughness $R a=0,2 \mu \mathrm{m}$.

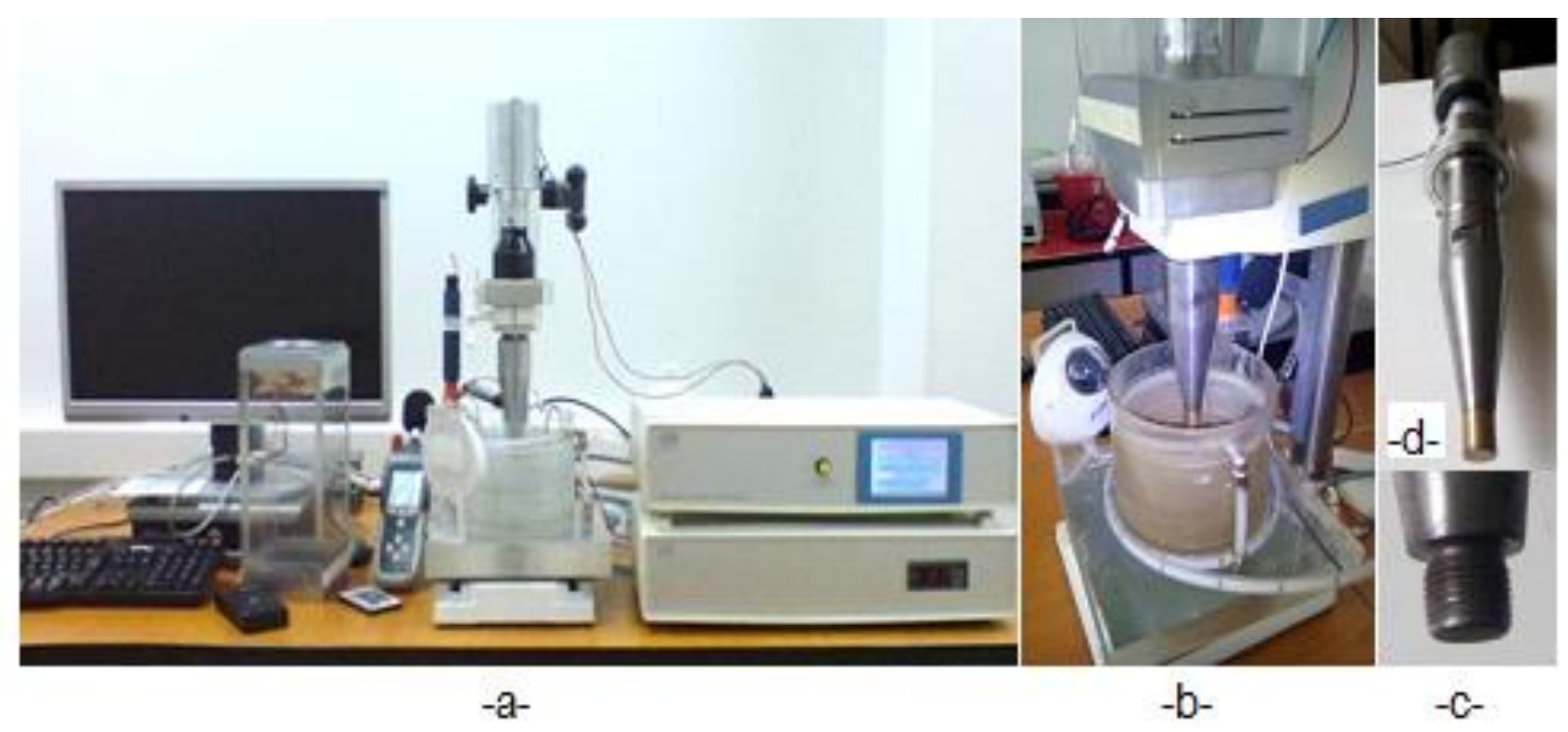

Figure 2 Standard vibrating device with piezoceramic crystals: $a$ - general image: $b$ - image during the cavitation attack; $c$ - the head of the sonotrode in which the cavitation sample is fixed; $d$ - the vibrating mechanical system with the sample fixed in the sonotrode.

The laboratory methodology, regarding the working condition and the research procedure (total duration and intermediate periods of the cavitation attack, liquid environment and its temperature, cleaning and washing of each cavitation sample, evaluation of mass losses) were performed in strict accordance with ASTM G32-2016 [4]. The surface topography of the cavitation samples was macro and micrographic investigated to reveal the mechanism responsible for increasing the stability to erosion and surface degradation. 


\section{EXPERIMENTAL RESULTS}

\subsection{Cavitation curves}

The diagrams shown in Figure 3 and Figure 4 presents the experimental results of the cavitation test, expressed by the average values obtained for the mass losses $M(t)$, respectively for the erosion rate $v(t)$ depending on the duration of the cavitation attack, for the sets consisting of stress relieving annealing samples and for those subjected to plasma nitriding thermochemical treatment. Both diagrams were drawn based on mass losses, $\Delta \mathrm{m}$ and velocities recorded at the end of each cavitation attack period, $\Delta t=5,10$ and 15 minutes, which were cumulated as the cavitation attack time was moving to a final duration of 165 minutes.

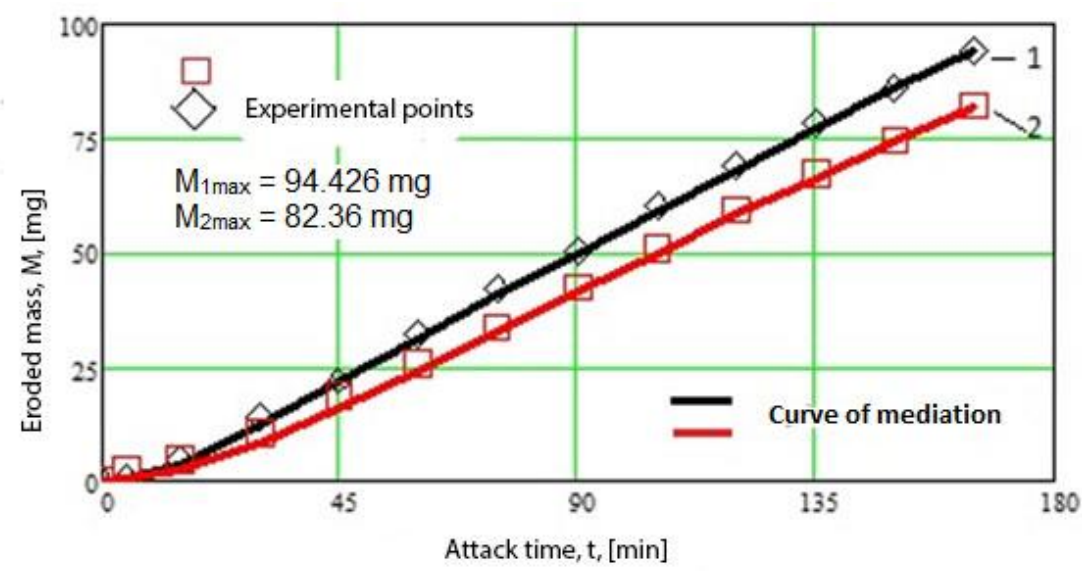

Figure 3 The variation of the eroded mass with the duration of the cavitation attack: 1 - stress relieving annealing; 2 - plasma nitriding

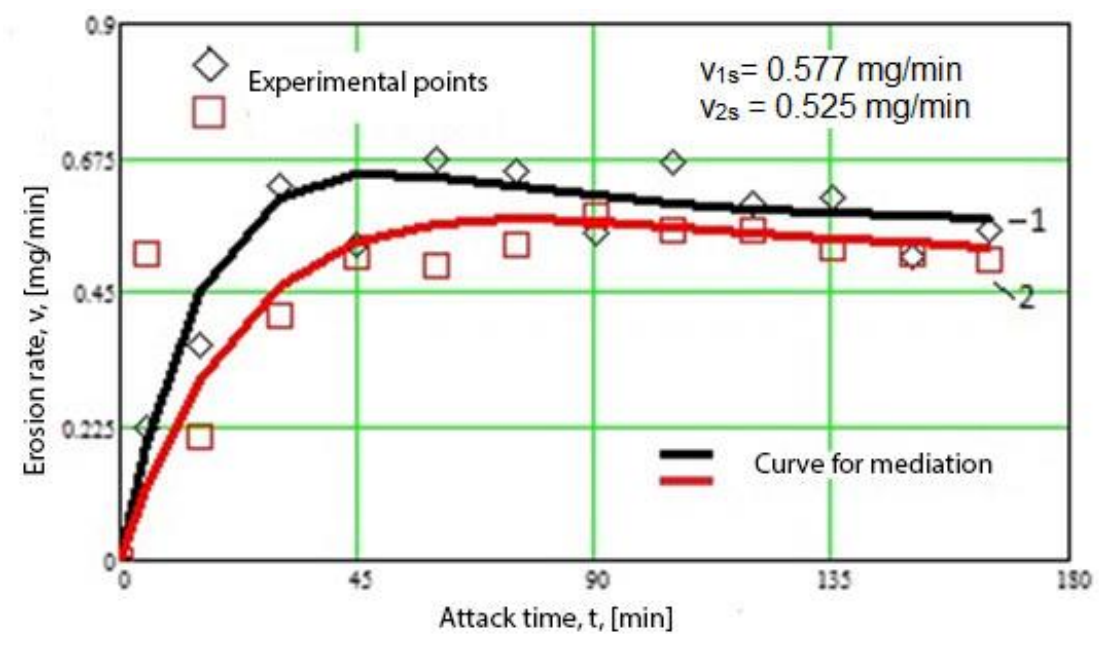

Figure 4 The variation of the erosion rate with the duration of the cavitation attack: 1 - stress relieving annealing; 2 - plasma nitriding

The data obtained are in concordance with those existing in other research papers $[2,8]$ and demonstrate that a slight improvement in cavitation erosion resistance is obtained following the application of plasma nitriding thermochemical treatment to gray cast iron with lamellar graphite.

If by applying the stress relieving annealing treatment the mass losses after the cavitation attack of 165 minutes were $94.426 \mathrm{mg}$ and the erosion rate was $0.577[\mathrm{mg} / \mathrm{min}$ ], plasma nitriding thermochemical treatment causes a decrease in mass loss by about $14.7 \%$, respectively the erosion rate by about $10 \%$. 


\subsection{Macro and micrographic examinations}

Figure 5 shows the macrography of the eroded surface of the gray cast iron subjected to the plasma nitriding thermochemical treatment, noticing clearly that the as the duration of the cavitation attack increases, the eroded area expands and the caverns become deeper.

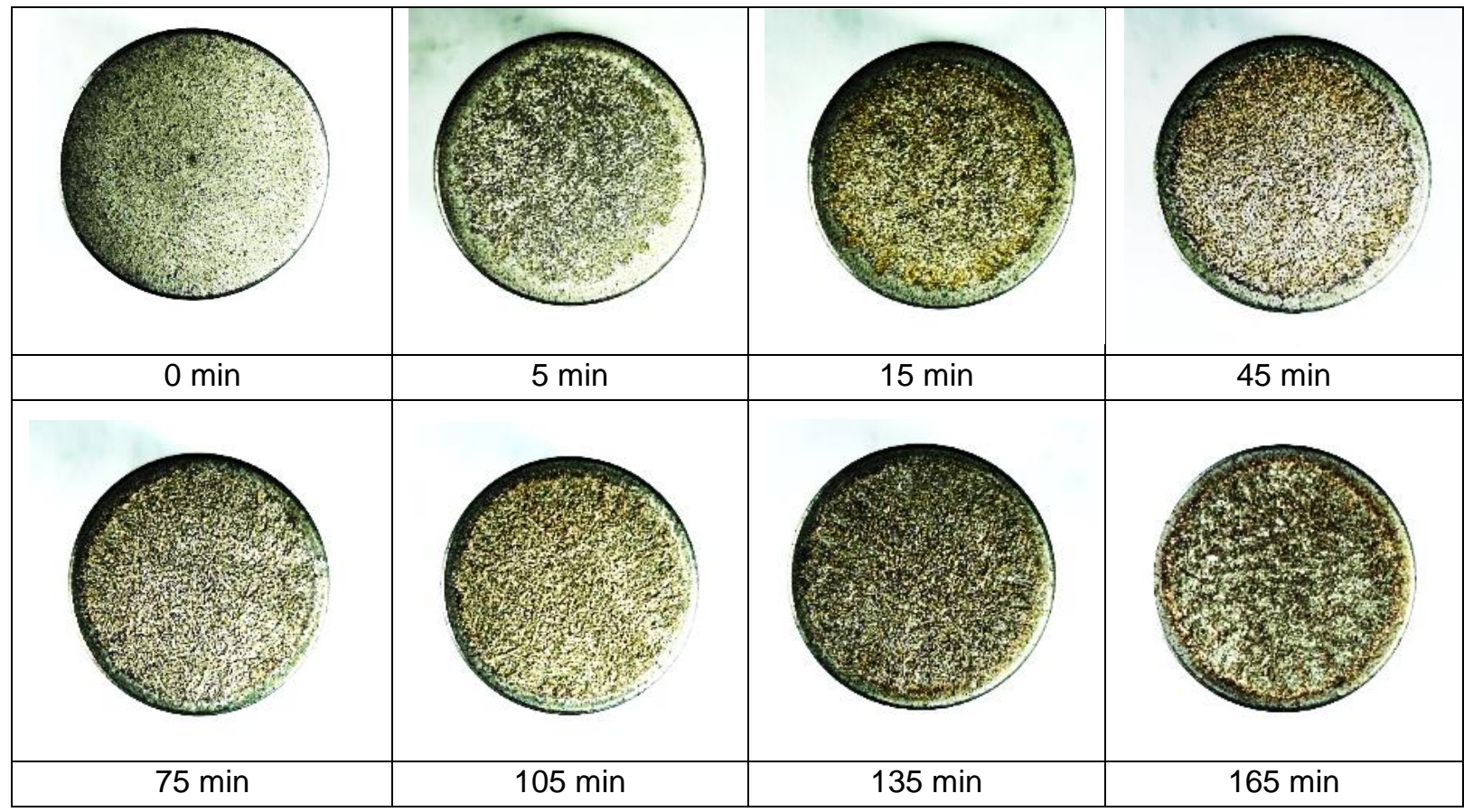

Figure 5 Macroscopic samples appearance of the surface nitride in plasma and exposed to cavitation at variable time durations

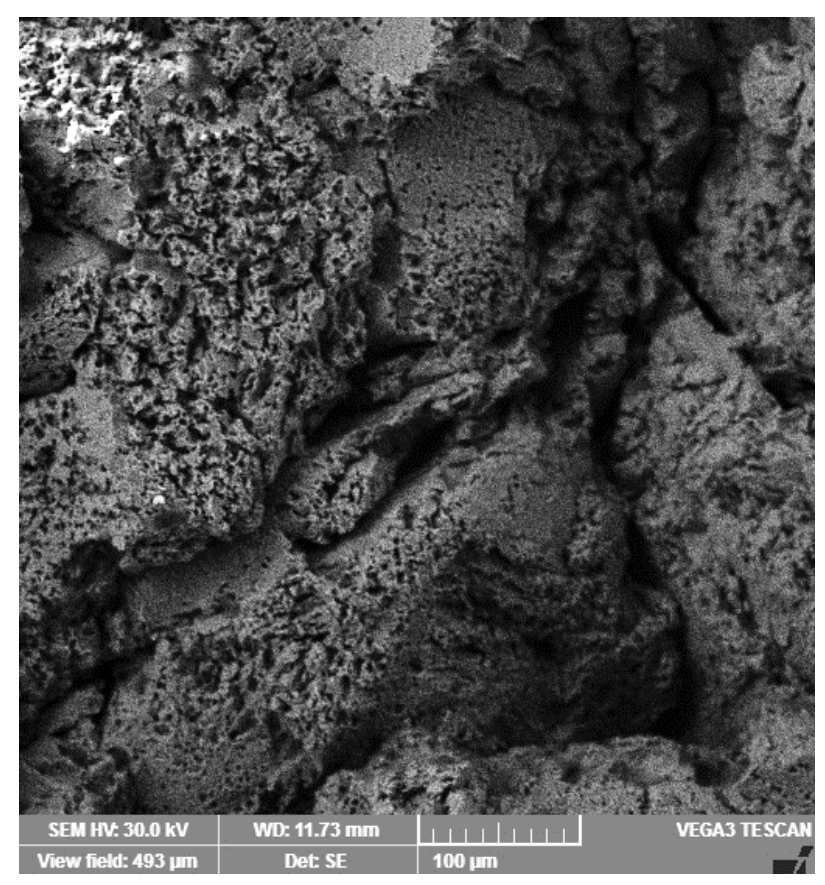

a)

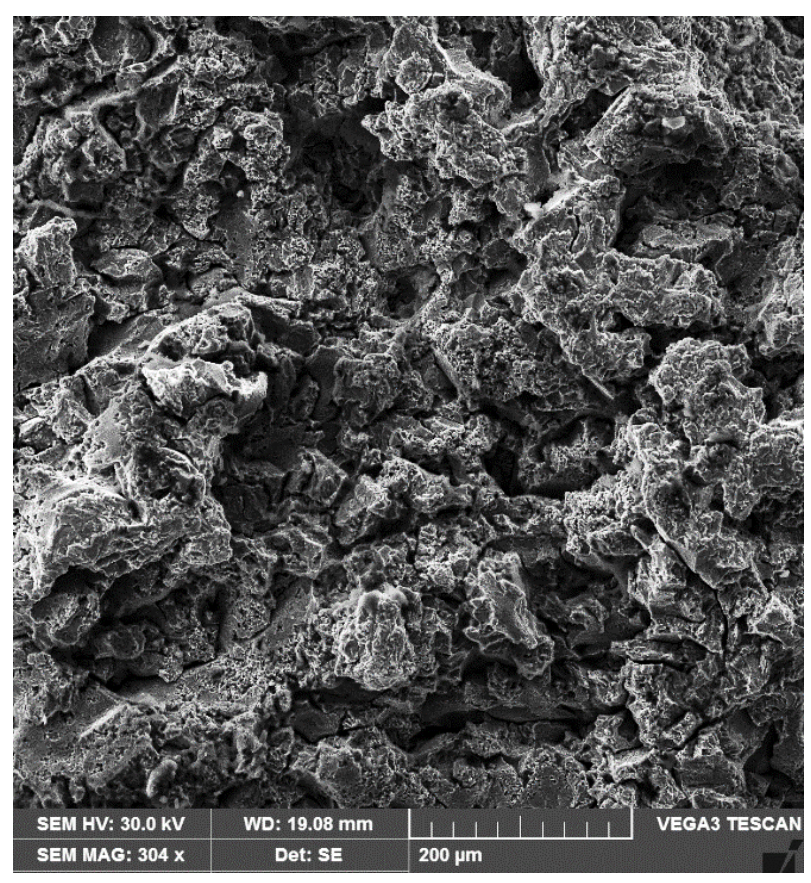

b)

Figure 6 SEM image of the tested surface at 165 minutes cavitation time: a - after stress relieving annealing; $b$ - after plasma nitriding 
Scanning electron microscopy examination of damaged surfaces after 165 minutes the cavitation attack shows that by the stress relieving annealed samples (Figure 6 a) a furrowing of the former areas with lamellar graphite and a coalescence of the initiated cracks in the metal matrix adjacent areas occurs. In opposite, the surface of the plasma nitride samples (Figure 6 b) is less damaged, the hard $\mathrm{Fe}_{\mathrm{x}} \mathrm{N}_{\mathrm{y}}$ nitride phases blocking the cavitation erosion wear phenomenon.

\section{CONCLUSIONS}

Compared to stress relieving annealing, the plasma nitriding thermochemical treatment at $530^{\circ} \mathrm{C}$ for $16 \mathrm{~h}$ applied to gray cast iron with perlitic matrix and lamellar graphite, is manifested by a reduction of mass loss of $14.7 \%$ and an erosion rate with about $10 \%$ after 165 minutes of cavitation attack.

The limited increase in cavitation resistance is justified by:

- Difficulties in the formation of homogeneous nitride phases due to the existing graphite on the material surface that plays the role of barrier;

- Sensitivity of nitride particles to stress concentration.

The topographies of the cavitated surfaces reveal a less pronounced degradation of the samples hardened by plasma nitriding thermochemical treatment.

\section{REFERENCES}

[1] MITELEA, I. Stiinta Materialelor vol. II. Timisoara: Editura Politehnica, 2010.

[2] NIE, X., WANG, L., YAO, Z., ZHANG, L., CHENG, F. Surface quality of gray cast iron in the context of nitriding and oxygen-sulphur nitriding. Surface and Coating Technology. 2005, vol. 200, pp. 1745-1750.

[3] KARAMIS, M.B., YILDIZLI, K. Surface modification of nodular cast iron: A comparative study on a graphite elimination. Materials Science and Engineering. 2010, vol. 527, pp. 5225-5229.

[4] ASTM G32-16. Standard method of vibratory cavitation erosion test. West Conshohocken, PA, USA: ASTM International, 2016.

[5] BORDEASU, I. Monografia Laboratorului de cercetare a eroziunii prin cavitatie al Universitatii Politehnica Timisoara (1960-2020). Timisoara: Editura Politehnica, 2020.

[6] RIEMSCHNEIDER, E., BORDEASU, I., MITELEA, I., UTU, I.D. Cavitation erosion of grey cast iron with pearlite microstructure. In: Metal $201726^{\text {th }}$ International Conference on Metallurgy and materials (Metal-2017). Brno, 2018, pp. 985-990.

[7] BORDEASU, I., MICU, L.M., MITELEA, I., UTU, I.D., PIRVULESCU, L.D., SARBU, N.A. Cavitation erosion of HVOF metal-ceramic composite coatings deposited onto Duplex stainless steel substrate. Revista de Materiale Plastice. 2016. vol. 54, no. 4, pp. 781-786.

[8] PARK, I.C., LEE, H.K., KIM, S.J. Microstructure and cavitation damage characteristics of surface treated gray cast iron by plasma ion nitriding. Applied Surface Science. 2019, vol. 47731, pp. 147-153. 